\title{
GENOTYPIC VARIABILITY IN SEED ACCUMULATION OF FOLIAR-APPLIED MOLYBDENUM TO COMMON BEAN ${ }^{(1)}$
}

\author{
Rogério Faria Vieira ${ }^{(2)}$, Trazilbo José de Paula Júnior ${ }^{(2)}$, José Eustáquio de Souza \\ Carneiro $^{(3)}$ \& Marina Viana Queiroz ${ }^{(4)}$
}

\begin{abstract}
SUMMARY
The genotypic variability in molybdenum (Mo) accumulation in common bean seeds has been demonstrated in cases in which soil is the main Mo source, but this variability is yet unknown when Mo is foliar-applied. Therefore, seed Mo concentrations (SMoCc) and seed Mo contents (SMoCt) of 12 genotypes were determined in four experiments in the Zona da Mata, Minas Gerais, Brazil, in which plants were sprayed with $600 \mathrm{~g} \mathrm{ha}^{-1} \mathrm{Mo}$. For comparison, two additional experiments without external Mo were conducted. Without Mo application, the average SMoCc was undetectable or $2.83 \mu \mathrm{g} \mathrm{g}^{-1}$, without significant differences among genotypes. On average, with Mo applications, SMoCc ranged from 14.7 to $25.0 \mu \mathrm{g} \mathrm{g}^{-1}$ and SMoCt, from 3.94 to $6.84 \mu \mathrm{g}$. 'Majestoso' was among the genotypes with the highest SMoCc in the four experiments. However, the large-seeded 'Jalo MG-65' and 'Carnaval' generally had higher SMoCt than the small-seeded 'Majestoso'. 'Ouro Negro' and especially 'Valente' were among the genotypes with the lowest SMoCc and SMoCt. The values of these variables were 61 and $90 \%$, respectively, higher for 'Majestoso' than those for 'Valente'. Our results suggest that common bean genotypes differ in their capacity to accumulate foliar-applied Mo in the seeds. Mo-rich seeds of large-seeded genotypes or of small-seeded of small-seeded genotypes with good capacity to accumulate Mo in seeds can be produced with relatively less Mo fertilizer.
\end{abstract}

Index terms: Phaseolus vulgaris, seed molybdenum content, foliar fertilization, growth habit.

(1) Received for publication on February 28, 2013 and approved on October 25, 2013.

(2) Researcher, Agricultural Research Institute of Minas Gerais - Epamig, Vila Gianetti, 47. CEP 36570-900 Viçosa (MG), Brazil. E-mail: rfvieira@epamig.br, trazilbo@epamig.br

(3) Professor, Plant Science Department, Universidade Federal de Viçosa (Federal University of Viçosa) - UFV, Campus UFV. Av. P. H. Rolfs, s/n. CEP 36570-900 Viçosa (MG), Brazil. E-mail: jesc@ufv.br

(4) Agronomy student, UFV. Undergraduate fellowship. E-mail: marinavqueiroz@gmail.com 


\title{
RESUMO: VARIABILIDADE GENOTÍPICA EMFEIJÃO-COMUMEMACUMULAR NA SEMENTE O MOLIBDÊNIO APLICADO NA FOLHAGEM
}

\begin{abstract}
A variabilidade genotípica em feijão-comum em acumular molibdênio (Mo) nas sementes foi demonstrada quando o solo é a principal fonte de Mo; entretanto, essa variabilidade ainda é desconhecida quando o Mo é aplicado na folhagem. Portanto, determinaram-se teores de Mo da semente (TMoS) e conteúdos de Mo da semente (CMoS) de 12 genótipos em quatro experimentos conduzidos na Zona da Mata, Minas Gerais, Brasil, nos quais pulverizaram-se as plantas com $600 \mathrm{~g} \mathrm{ha}^{-1}$ de Mo. Para comparação, conduziram-se mais dois experimentos sem aplicação de Mo. Nesse caso, não foi detectado Mo na semente ou o TMoS médio foi $2,83 \mu \mathrm{g} \mathrm{g}^{-1}$, sem diferença significativa entre genótipos. Em média, com aplicação de Mo, os TMoS variaram de 14,7 a 25, $0 \mathrm{\mu g} \mathrm{g}^{-1}$ e os CMoS, de 3,94 a 6,84 $\mathrm{\mu g}$. 'Majestoso' ficou entre os genótipos com os mais altos TMoS nos quatro experimentos. No entanto, as sementes grandes de 'Jalo MG-65' $e$ 'Carnaval'geralmente apresentaram mais altos CMoS que as sementes pequenas da 'Majestoso'. 'Ouro Negro' e, sobretudo, 'Valente' ficaram entre os genótipos com os mais baixos TMoSe CMoS. Os valores dessas variáveis foram 61 e 90 \%, respectivamente, mais altos na 'Majestoso' que na 'Valente'. Os resultados sugerem que genótipos de feijão-comum diferem na capacidade de acumular nas sementes o Mo aplicado na folhagem. Sementes enriquecidas com Mo de genótipos de sementes grandes ou de genótipos de sementes pequenas bons acumuladores de Mo na semente podem ser produzidas com dose relativamente menor de fertilizante molíbdico.
\end{abstract}

Termos de indexação: Phaseolus vulgaris, conteúdo de molibdênio da semente, adubação foliar, hábito de crescimento.

\section{INTRODUCTION}

Molybdenum (Mo) is a constituent of three enzymes related to the nitrogen $(\mathrm{N})$ nutrition of plants: nitrogenase, nitrate reductase and xanthine dehydrogenase. These enzymes act, respectively, in the acquisition of $\mathrm{N}$ by means of biological $\mathrm{N}$ fixation, in $\mathrm{N}$ utilization absorbed as nitrate, and in the degradation of purine (Mendel, 2011). The N concentration in Mo-deficient common bean plants may therefore be low, due to the reduced activity of these enzymes. Xanthine dehydrogenase is also involved in plant resistance to disease and drought and leaf senescence. Two other plant enzymes contain Mo: sulfide oxidase and aldehyde oxidase. The latter is involved in the synthesis of abscisic acid, which plays an important role in plant growth and development and in the adaptive response to various stress environments (Mendel, 2011). Sulfide oxidase is involved in cell detoxification of excess sulfide (Mendel, 2011) and in the degradation of sulfurcontaining amino acids (Kaiser et al., 2005).

In the region of Zona da Mata of Minas Gerais, Mo applied to common bean leaves is the most commonly used method to correct soil Mo deficiency. Treating seeds with molybdenum fertilizer is also effective, but can be toxic to rhizobia (Campo et al., 2009). The plant use efficiency of Mo applied to foliage is higher than that of Mo applied to the soil along with other fertilizers (Abreu et al., 2007). Therefore, the Mo rate required for foliar application is lower than for soil application. Foliar Mo application also allows an even field distribution at low cost, because the Mo fertilizer can be added to the pesticide solution (Silva et al., 2003). In the region of Zona da Mata, foliar Mo fertilization should be applied between 14 and $28 \mathrm{~d}$ after emergence (DAE) (Berger et al., 1996) at a rate between 70 and $100 \mathrm{~g} \mathrm{ha}^{-1}$ Mo (Berger et al., 1996; Amane et al., 1999; Pessoa et al., 2001). In this region, Mo fertilization can increase common bean yields up to three times (Pessoa et al., 2001), with no need for $\mathrm{N}$ topdressing (Vieira et al., 1992, Berger et al., 1996; Amane et al., 1999).

The plant requirement for Mo is one of the lowest, compared to the other micronutrients. Therefore, large seeds as those of common bean (Phaseolus vulgaris L.) and soybean [Glycine max (L.) Merr.] can supply a plant with Mo when the soil is Mo-deficient. Morich seeds of common bean and soybean can be produced in Mo-poor soils. To enrich these seeds with Mo in these soils, the plants are sprayed with Mo rates between 240 and 1,600 $\mathrm{g} \mathrm{ha}^{-1}$ (Vieira et al., 2005; Kubota et al., 2008; Campo et al., 2009; Vieira et al., 2011a,b; Pacheco et al., 2012; Almeida et al., 2013). Molybdenum applied to the foliage can be transferred within $24 \mathrm{~h}$ to other plant parts (Williams et al., 2004). This rapid Mo transport in the plant probably also occurs when Mo-rich seeds are used. Therefore, the Mo contained in the seed becomes available to the plant quicker than that applied to the foliage. This prompt plant availability when Mo-rich seeds are used can benefit nitrogenase activity in the early vegetative stage of common bean (Almeida et al., 2013). Small farmers can benefit most from the use of these seeds, because they usually have no access to Mo fertilizer or are unaware of the advantages Mo fertilization can have on common bean.

In soybean, spraying plants with a total rate of $800 \mathrm{~g} \mathrm{ha}^{-1}$ Mo increased the seed Mo content by $3,000 \%$ (Campo et al., 2009). In regions with Mo-poor soils, as 
in Zona da Mata, plants grown from common bean seeds containing $3.6 \pm 0.7 \mu \mathrm{g}$ Mo per seed or more (high Mo content) did not respond to Mo spraying, unlike seeds with low Mo content (Vieira et al., 2011b). Seeds with high Mo content were derived from plants sprayed with $1,000 \mathrm{~g} \mathrm{ha}^{-1}$ Mo and those with low Mo content $(0.007 \pm 0.001$ or $0.248 \pm 0.057 \mu \mathrm{g}$ Mo per seed) from plants sprayed with water or $90 \mathrm{~g} \mathrm{ha}^{-1} \mathrm{Mo}$, respectively (Vieira et al., 2010). Split Mo applications can induce higher seed Mo contents than a single application (Vieira et al., 2005).

The price of Mo increased greatly in recent years (Guang-Yi et al., 2012). One way to use Mo fertilizer efficiently to increase Mo content in seed is to know the genotypic variability in the capacity to accumulate foliar-applied Mo in the seeds. When the soil is the main Mo source, the common bean genotypes differ in the capacity to accumulate Mo in seeds (Franco \& Munns, 1981; Brodrick \& Giller, 1991b; Brodrick et al., 1995). However, the genotypic variability in the capacity to accumulate Mo in seeds has not been studied so far for foliar-applied Mo. Our objective was to evaluate genotypes from four Brazilian common bean breeding programs for their capacity to accumulate foliar-applied Mo in the seeds.

\section{MATERIAL AND METHODS}

Four field experiments were conducted in which plants of 12 common bean genotypes were sprayed with $600 \mathrm{~g} \mathrm{ha}^{-1}$ Mo. Locations and soils of common bean fields in the Zona da Mata, State of Minas Gerais, Brazil, were chosen where common bean had responded positively to foliar-applied Mo in previous years. In Oratórios, two experiments were installed in 2008 (April 10 and July 11) and one in 2010 (March 18). In Coimbra, one experiment was installed on March 29, 2010. In 2010, adjacent to the two experiments with Mo application (Coimbra and Oratórios), an experiment without external Mo application was carried out for comparison.

In Oratórios, the experiments were carried out at an experimental station $\left(20^{\circ} 24^{\prime} 12^{\prime \prime} \mathrm{S}, 42^{\circ} 49^{\prime} 08^{\prime \prime} \mathrm{W}\right.$; $478 \mathrm{~m}$ ) of the Agricultural Research Institute of Minas Gerais (Epamig); in Coimbra, in an area $\left(20^{\circ} 49^{\prime} 44^{\prime \prime} \mathrm{S}\right.$, $42^{\circ} 45^{\prime} 47 \mathrm{~W} ; 716 \mathrm{~m}$ ) of the Federal University of Viçosa (UFV). The soils of these areas are classified as Ultisol (Embrapa, 2006), with $560 \mathrm{~g} \mathrm{~kg}^{-1}$ clay, $190 \mathrm{~g} \mathrm{~kg}^{-1}$ silt, and $250 \mathrm{~g} \mathrm{~kg}^{-1}$ sand in Coimbra, and 270, 150 and $580 \mathrm{~g} \mathrm{~kg}^{-1}$, respectively, in Oratórios. Other soil properties are shown in table 1 . The soils were prepared by disc plowing followed by three diskings before planting.

Eleven common bean cultivars and line VC-8 were used (Table 2). These genotypes were derived from four common bean breeding programs in Brazil. The number of genotypes of each plant Type (III, II or I) represents approximately the proportion of use of each of these types by Brazilian farmers. Type III plants have a semiprostrate to prostrate indeterminate growth habit; Type II upright indeterminate growth habit; and Type I plants have a determinate growth habit. The cultivars Jalo MG 65 and Carnaval MG have large seeds (Andean origin) and the other genotypes small seeds (Mesoamerican origin). The seeds of the 12 genotypes were obtained from the UFV. These seeds were sown together for seed multiplication, without external Mo application, in an experimental area of the UFV in Coimbra.

A randomized block design with five (April 2008) or four replications (other experiments) was used. The plots consisted of one (2008) or three (2010) 2-m rows, spaced $0.5 \mathrm{~m}$ apart, with a density of 15 seeds per meter. In 2010 , the outer rows were the borders. In 2008, the genotypes of neighboring plots were the lateral borders, and cultivar Ouro Vermelho was planted as the external border of the experiments. Therefore, an area of $1 \mathrm{~m}^{2}$ was evaluated in both years.

In 2008, Mo (in $\mathrm{g} \mathrm{ha}^{-1}$ ) as sodium molybdate was split as follows: 300 in the V4 growth stage (third trifoliate leaf) and 300 in the R6 stage (flowering). In that year, the early maturing cultivar Carnaval was sown on the same day as the others. On the days of Mo spraying, the plants of Carnaval were in the R5 stage (pre-flowering) and R7 stage (early pod formation), respectively. In 2010, Mo (in $\mathrm{g} \mathrm{ha}^{-1}$ ) was split in: 100 in V4, 250 in R5 and 250 in R7. At that time, cultivar Carnaval was sown $7 \mathrm{~d}$ after the others so that Mo was sprayed in the three scheduled growth stages. In both experiments in 2010, in which no Mo was applied, the genotypes were sown on the same day. A $\mathrm{CO}_{2}$ sprayer equipped with two XR 11002 cone nozzles, spaced $0.5 \mathrm{~m}$ apart, with a flow rate of $225 \mathrm{~L} \mathrm{ha}^{-1}$ at a pressure of $207 \mathrm{kPa}$ was used. Dodecylbenzene sulfonic acid spreader-sticker at $20 \mathrm{~g} \mathrm{~L}^{-1}$ was added to the Mo solution.

In Coimbra, a basal fertilization of $24 \mathrm{~kg} \mathrm{ha}^{-1} \mathrm{~N}$, $36 \mathrm{~kg} \mathrm{ha}^{-1} \mathrm{P}$, and $39 \mathrm{~kg} \mathrm{ha}^{-1} \mathrm{~K}$ was applied in the sowing furrow; in Oratórios, $14 \mathrm{~kg} \mathrm{ha}^{-1} \mathrm{~N}, 21 \mathrm{~kg} \mathrm{ha}{ }^{-1}$ $\mathrm{P}$, and $23 \mathrm{~kg} \mathrm{ha}^{-1} \mathrm{~K}$. Both fertilizations were based on recommendation of Barbosa \& Gonzaga (2012) for target yields above $2500 \mathrm{~kg} \mathrm{ha}^{-1}$. Rhizobium inoculant was not used. In the season prior to the experiments, the common bean plants grown in the plots had produced many nodules, indicating the presence of native rhizobia strains in these soils. Around $20 \mathrm{DAE}$, $150 \mathrm{~kg} \mathrm{ha}{ }^{-1}$ urea was applied along the rows, as recommended by Barbosa \& Gonzaga (2012), for target yields between 2500 and $3500 \mathrm{~kg} \mathrm{ha}^{-1}$. Weeds were controlled with fomesafen ( $\left.150 \mathrm{~g} \mathrm{ha}^{-1}\right)$ and fluazifop-pbutyl $\left(200 \mathrm{~g} \mathrm{ha}^{-1}\right)$ and, where necessary, also with surface hoeing. Pests were controlled with methamidophos (500 mL ha ${ }^{-1}$ ) or chlorpyriphos $\left(400 \mathrm{~mL} \mathrm{ha}^{-1}\right)$. Leaf diseases were preventively controlled with epoxiconazole $\left(12.5 \mathrm{~mL} \mathrm{ha}^{-1}\right)$ and azoxystrobin $\left(50 \mathrm{~g} \mathrm{ha}^{-1}\right)$, applied alternatingly. At sowing, and then every $3 \mathrm{~d}$ until 
Table 1. Chemical characteristics of soils in the $0-20 \mathrm{~cm}$ layer in the experimental areas prior to the experiments

\begin{tabular}{|c|c|c|c|c|}
\hline \multirow{2}{*}{ Soil property ${ }^{(1)}$} & \multicolumn{2}{|c|}{ Oratórios } & \multicolumn{2}{|c|}{ Coimbra } \\
\hline & April $2008^{(2)}$ & July 2008 & March 2010 & March 2010 \\
\hline $\mathrm{pH}\left(\mathrm{H}_{2} \mathrm{O}\right)(1: 2.5)$ & 6.4 & 6.4 & 5.8 & 4.7 \\
\hline $\mathrm{P}, \mathrm{mg} \mathrm{dm} \mathrm{m}^{-3}$ & 32 & 73 & 31 & 11 \\
\hline $\mathrm{K}, \mathrm{mg} \mathrm{dm}{ }^{-3}$ & 120 & 132 & 112 & 84 \\
\hline $\mathrm{Al}, \mathrm{cmol}_{\mathrm{c}} \mathrm{dm}^{-3}$ & 0.0 & 0.0 & 0.0 & 0.5 \\
\hline $\mathrm{Ca}, \mathrm{cmol}_{\mathrm{c}} \mathrm{dm}^{-3}$ & 2.4 & 3.5 & 2.9 & 1.4 \\
\hline $\mathrm{Mg}, \mathrm{cmol}_{\mathrm{c}} \mathrm{dm}^{-3}$ & 1.1 & 1.2 & 0.9 & 0.5 \\
\hline Base saturation, \% & 79 & 79 & 59 & 31 \\
\hline $\mathrm{H}+\mathrm{Al}, \mathrm{cmol}_{\mathrm{c}} \mathrm{dm}^{-3}$ & 0.99 & 1.32 & 2.81 & 4.79 \\
\hline $\operatorname{CEC}(\mathrm{T}), \mathrm{cmol}_{\mathrm{c}} \mathrm{dm}^{-3}$ & 4.80 & 6.36 & 6.90 & 6.90 \\
\hline Organic matter, dag $\mathrm{kg}^{-1}$ & 1.1 & 2.1 & 2.5 & 3.0 \\
\hline
\end{tabular}

(1) $\mathrm{P}$ and $\mathrm{K}$ extracted by Mehlich-1 solution. $\mathrm{Al}, \mathrm{Mg}$, and Ca extracted by $\mathrm{HCl} 1 \mathrm{~mol} \mathrm{~L}^{-1}$. Base saturation $=[(\mathrm{K}+\mathrm{Ca}+\mathrm{Mg}) / \mathrm{T}] \mathrm{x} 100$, in which $\mathrm{T}=\mathrm{K}+\mathrm{Ca}+\mathrm{Mg}+(\mathrm{H}+\mathrm{Al}) ; \mathrm{H}+\mathrm{Al}$ extracted by a solution of calcium acetate $0.5 \mathrm{~mol} \mathrm{~L}^{-1}, \mathrm{pH} 7.0 .{ }^{(2)}$ Location and month and year of the installation of the experiment.

Table 2. Seed and plant characteristics of common bean genotypes and institutions of origin

\begin{tabular}{lcccc}
\hline Genotype & Commercial class ${ }^{(1)}$ & Seed size & Plant type $^{(2)}$ & Origin $^{(3)}$ \\
\hline Ouro Vermelho & red & small & III & UFV \\
Pérola & carioca & small & III & Embrapa \\
BRSMG Majestoso & carioca & small & III & UFLA \\
VC-8 & carioca & small & III & UFV \\
Ouro Negro & black & small & III & Embrapa \\
BRSMG Madrepérola & carioca & small & III & UFV \\
BRSMG Talismã & carioca & small & III & UFLA \\
BRSMG Pioneiro & carioca & small & II & UFV \\
Jalo MG-65 & jalo & large & III & Epamig \\
Carnaval MG & cranberry & large & Epamig \\
BRS Valente & black & small & II & Embrapa \\
BRS Horizonte & carioca & small & Embrapa \\
\hline
\end{tabular}

(1) carioca: beige with light brown stripes; jalo: beige. ${ }^{(2)} \mathrm{I}$ :determinate growth habit, life cycle between 65 and 75 d; II indeterminate upright growth habit; III: indeterminate semiprostrate to prostrate growth habit. ${ }^{(3)}$ Institutions of origin: UFV - Federal University of Viçosa, Embrapa - Brazilian Agricultural Research Corporation, UFLA - Federal University of Lavras, Epamig Agricultural Research Institute of Minas Gerais.

seedling emergence, plots were sprinkler irrigated with $2.0 \mathrm{~cm}$ of water. Then irrigation was applied weekly until the beginning of flowering with approximately $4.0 \mathrm{~cm}$ of water. In the reproductive stage, approximately $5.0 \mathrm{~cm}$ of water were applied in weekly irrigations.

The canopy closure, seed yield, 100-seed mass, seed Mo concentration (SMoCc), and seed Mo content (SMoCt) were evaluated. Canopy closure was estimated visually in Coimbra at the stages V4, R5, and R7 by observing each plot from one end (looking down the rows) and visually estimating the proportion of soil surface visible between the rows (100\% representing complete soil cover) (Kane \& Grabau, 1992). Seed yield and 100-seed mass were estimated with an approximate moisture content of $13 \%$ (wet basis). Two hundred seeds were oven-dried at $72{ }^{\circ} \mathrm{C}$ for $72 \mathrm{~h}$ to estimate the 100-seed dry mass. The dried seeds were ground and subjected to nitric perchloric acid digestion, with subsequent analysis in an atomic emission spectrometer with inductively-coupled plasma (ICP-OES, Perkin-Elmer Optima 3300 DV) to determine the SMoCc. The SMoCt represents the amount of Mo accumulated in seed that will be available to the plant grown from it. For its calculation, SMoCc, in $\mu \mathrm{g} \mathrm{g}^{-1}$, was multiplied by the average mass of one dry seed, in $\mathrm{g}$.

The data were subjected to analysis of variance, and the means grouped by the Scott-Knott test at $5 \%$. 


\section{RESULTS AND DISCUSSION}

\section{Canopy closure and yield}

In 2010, in Coimbra, the canopy closure of the eight Type III genotypes was $50-60 \%$ in the V4 growth stage, $70-85 \%$ in the R5 stage, and $80-87 \%$ in R7 stage. The canopy closure of Type II cultivars (Pioneiro, Horizonte, and Valente) was 40 or $45 \%$ in the V4 stage, 50 or $55 \%$ in the R5 stage, and 60 or $75 \%$ in the R7 stage. Cultivar Carnaval (Type I) had a canopy closure of $30 \%$ in V4, $45 \%$ in R5 and $50 \%$ in R7. These results clearly indicate that since the V4 stage, when Mo was first sprayed, Type III plants covered more space between rows than either Type II or Type I plants. The characteristics of these three types of plants explain these differences. Type III have more nodes and more lateral branches than Type II plants, while the latter have more lateral branches and more nodes than Type I plants (Vieira et al., 2006).

The average yields in the four experiments were high, ranging from 341 (Oratórios, March 2010, $\mathrm{CV}=22 \%$ ) to $486 \mathrm{~g} \mathrm{~m}^{-2}$ (Oratórios, July 2008, CV = $19 \%)$. In Coimbra, the CV was $14 \%$; in Oratórios (April 2008) $20 \%$. Only in Coimbra the effect of genotype on yield was significant, and genotypes were clustered in three groups. The group of highestyielding genotypes in Coimbra comprised Ouro Vermelho, Pérola, Majestoso, VC-8, Ouro Negro, Madrepérola, Talismã, and Pioneiro.

Molybdenum concentration and content in the seeds of genotypes without Mo fertilization

The yield in the two 2010 experiments without external Mo application was around $350 \mathrm{~g} \mathrm{~m}^{-2}$. In Coimbra, two yield-related groups were clustered (CV $=14 \%$, data not shown). In Oratórios (CV = $22 \%)$, genotypes had no significant influence on yield.

In Coimbra, no Mo was detected in seeds of the genotypes. In Oratórios, Mo was detected in the seeds, but genotypes did not affect $\mathrm{SMoCc}[\mathrm{F}(11,33)=0.885$, $\mathrm{p}=0.56, \mathrm{CV}=14 \%]$. The average SMoCc in Oratórios was $2.83 \mu \mathrm{g} \mathrm{g}^{-1}$, whereas SMoCt varied from 0.61 to $1.32 \mu \mathrm{g}$, depending on the genotype (data not shown). These results suggest that the soil in Coimbra is poorer in Mo than the soil in Oratórios, since SMoCc indicates the Mo availability in the soil (Brodrick et al., 1995). According to these authors, the difference among genotypes in the capacity to accumulate Mo in seed is less pronounced in Mo-poor soils, which may be the reason for the absence of a significant effect of genotypes on SMoCc, when no external Mo was used.

\section{Mo concentration and content in the seeds of Mo-fertilized genotypes}

In 2008, the average SMoCc of the genotypes was
$24.2 \mu \mathrm{g} \mathrm{g}^{-1}$ in the experiment installed in April, and $25.0 \mu \mathrm{g} \mathrm{g}^{-1}$ in that installed in July; in 2010 , in the experiments installed in March, the average $\mathrm{SMoCc}$ was $14.7 \mu \mathrm{g} \mathrm{g}^{-1}$ in Coimbra and $22.2 \mu \mathrm{g} \mathrm{g}^{-1}$ in Oratórios. The average SMoCt was, respectively, 6.39 and $6.84 \mu \mathrm{g}$ in 2008 and 3.94 and $5.87 \mu \mathrm{g}$ per seed in 2010. The lowest mean values of SMoCc and SMoCt in 2010, especially in Coimbra, reflect the lower soil $\mathrm{pH}$ in that year (Table 1). Plants grown in soil at $\mathrm{pH}$ 4.7 (Coimbra, 2010) may have less available Mo for uptake than when grown in soil with pH 6.4 (2008), because for every unit increase in $\mathrm{pH}$ above 3.0, the solubility of $\mathrm{MoO}_{4}-2$ increases 100 times (Lindsay, 1979).

The effect of genotypes on SMoCc and SMoCt was significant in all four experiments (Figures 1 and 2). The SMoCc ranged from 9.1 (Valente, Figure 2a) to $32.7 \mu^{-1} g^{-1}$ (Majestoso, Figure 1a). These high values of SMoCc compared to those obtained when no Mo

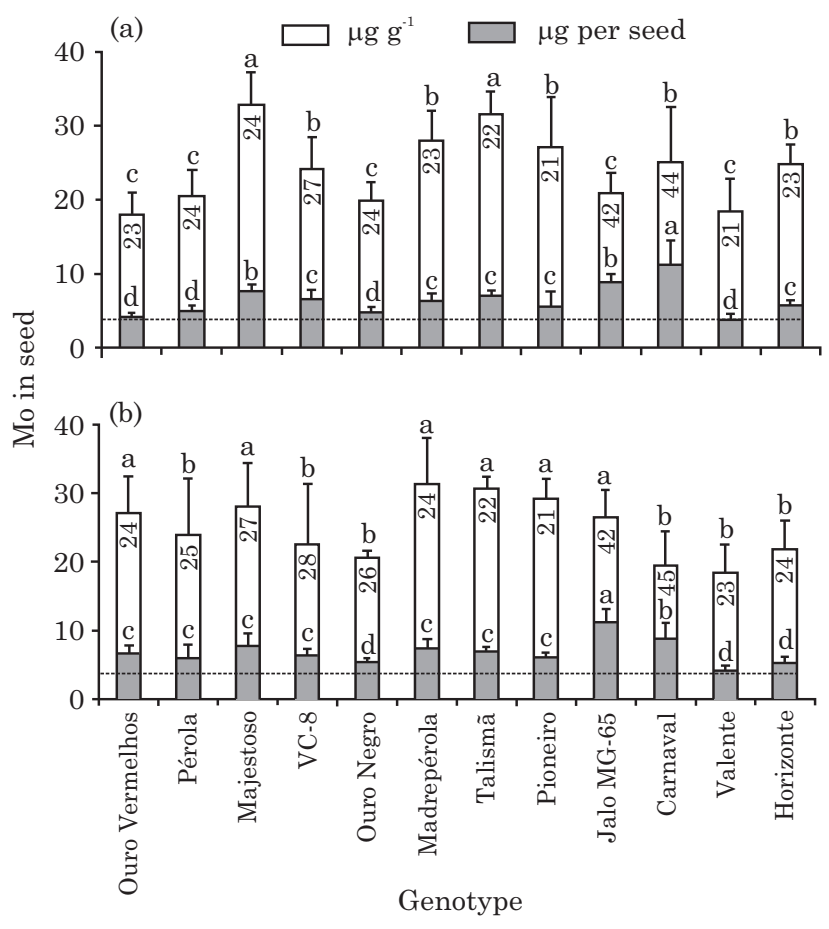

Figure 1. Effect of molybdenum (Mo) sprayed on 12 common bean genotypes at V4 (300 $\left.\mathrm{g} \mathrm{ha}^{-1}\right)$ and R6 growth stages (300 $\left.\mathrm{g} \mathrm{ha}^{-1}\right)$ on the Mo seed concentration ( $\square$ ) and content ( $\square$ ) in Oratórios in the experiments of (a) April 2008 and (b) July 2008. The filling of the white bars represents the 100 -seed dry mass (in g). The seed Mo content ( $\mu \mathrm{g}$ per seed) was calculed by multiplying the mass of one dry seed (in g) by the seed Mo concentration (in $\mu \mathrm{g} \mathrm{g}^{-1}$ ). The horizontal dotted line represents the seed Mo content $(3.6 \mu \mathrm{g})$ at which common bean does not respond to Mo fertilization (Vieira et al., 2011b). Thin bars represent the standard deviation. 


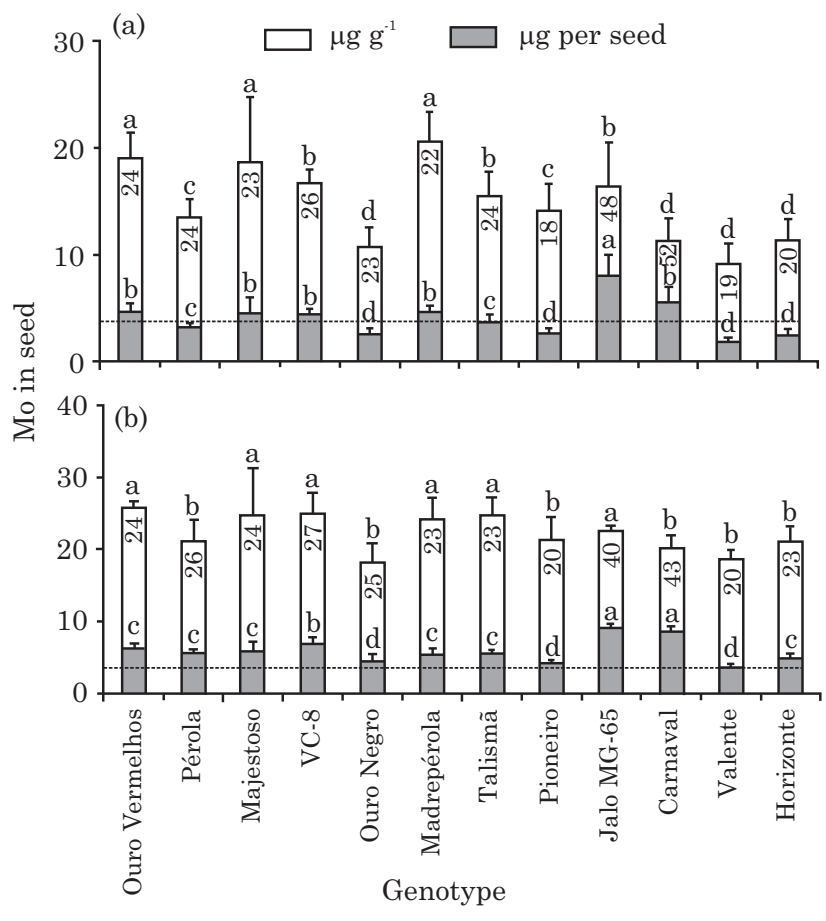

Figure 2. Effect of molybdenum (Mo) sprayed on 12 common bean genotypes at V4 (100 $\left.\mathrm{g} \mathrm{ha}^{-1}\right)$, R5 (250 $\mathrm{g}$ ha-1), and $\mathrm{R} 7$ growth stages (250 $\left.\mathrm{g} \mathrm{ha}^{-1}\right)$ on the Mo seed concentration $(\square)$ and content ( $\square$ ) in the 2010 experiments in (a) Coimbra and (b) Oratórios. The filling of the white bars represents the 100 -seed dry mass (in g). The seed Mo content ( $\mu$ g per seed) was calculed by multiplying the mass of one dry seed (in g) by the seed Mo concentration (in $\mu \mathrm{g} \mathrm{g}^{-1}$ ). The horizontal dotted line represents the seed Mo content $(3.6 \mu \mathrm{g})$ at which common bean does not respond to Mo fertilization (Vieira et al., 2011b). Thin bars represent the standard deviation.

was applied, clearly show that foliar-applied Mo increases the SMoCc substantially, as observed by Vieira et al. (2005, 2010), Pacheco et al. (2012), and Almeida et al. (2013). The SMoCt ranged from 1.75 (Valente, Figure 2a) to $11.2 \mu$ g per seed (Jalo MG- 65, Figure 1b).

With the exception of Pioneiro (Type II) in 2008 (Figure 1b), the groups with the highest SMoCc were formed of Type III genotypes (Figures 1 and 2). Cultivar Majestoso (Type III) was in the group with the highest SMoCc in all four experiments, and cultivars Ouro Vermelho, Madrepérola and Talismã (Types III) were in this group in three experiments. The greater canopy closure of Type III plants in the growth stages in which Mo was sprayed on foliage may have increased the interception of Mo solution by plants. Pérola, Ouro Negro (Types III), Valente, Horizonte (Types II), and Carnaval (Type I) were never present in the group of genotypes with highest SMoCc.
The absence of some Type III genotypes from the group of genotypes with highest SMoCc indicates that other mechanisms, aside from canopy closure, influenced the SMoCc.

Cultivar Majestoso belonged to a group with higher SMoCc than Ouro Negro and Pérola (Figures 1 and 2), in spite of having been derived from a cross between Ouro Negro and Pérola (Paula Júnior et al., 2010). On the average of the four experiments, Majestoso had a $50 \%$ higher SMoCc than Ouro Negro and $32 \%$ higher than Pérola. The greatest SMoCc difference between genotypes, however, was $61 \%$ (Majestoso vs. Valente). Franco \& Munns (1981) and Brodrick et al. (1995) reported a 3.5 and 5 -fold difference in SMoCc between genotypes, respectively, although in these studies the Mo sources for the plants were seed and soil. Ouro Negro nodulates well (Paula Júnior et al., 2010), and the nodules are strong Mo sinks (JacobNeto et al., 1988; Brodrick \& Giller 1991a). Physiologically, the ability of a genotype to accumulate Mo in seeds is associated with its capacity to re-transfer Mo from the roots, nodules and pod walls to the seeds (Brodrick \& Giller, 1991b).

Cultivar Jalo MG-65 (Figures $1 \mathrm{~b}$ and 2a) or Carnaval (Figure 1a), or both (Figure 2b), were in the group of genotypes with the highest SMoCt. These results were expected because the seed mass of these two cultivars is almost twice as high as that of the other genotypes. On average, the SMoCc of Jalo MG65 (Type III) was $15 \%$ higher than that of Carnaval (Type I). However, because of the higher seed mass of Carnaval relative to Jalo MG-65, the SMoCt of Carnaval was $9 \%$ higher than that of Jalo MG-65. Carnaval is an early-maturing cultivar. In 2008, plants of Carnaval were sprayed in R5 and R7, in later stages than those of the other genotypes (V4 and R6). In that year, Carnaval was not among the genotypes with highest SMoCc. The difference of 7-10 d in the life cycle of Carnaval compared to the other genotypes may have compromised the comparison of SMoCc among genotypes. However, in 2010, when Carnaval was sown a week later than the other genotypes, in order to synchronize the growth stages of all plants, once again Carnaval was not among the genotypes with the highest SMoCc. Therefore, in 2008, if spraying Mo on plants of Carnaval in later growth stages than on plants of the other genotypes caused any bias, the magnitude of this bias was small. The SMoCt of Carnaval and Jalo MG-65 was clearly above $3.6 \mu \mathrm{g}$ (Figures 1 and 2). Plants grown from seeds with such as high SMoCt do not respond to Mo fertilization in Mo and/or N-poor soil (Vieira et al., 2011b; Almeida et al., 2013).

In one of the experiments in 2010 , line VC- 8 had the highest SMoCt among the genotypes of Mesoamerican origin (Figure $2 \mathrm{~b}$ ). In the experiment set up in April 2008, Majestoso had the highest SMoCt of these small-seeded genotypes (Figure 1a). In the other two experiments, the SMoCt among cultivars 
Ouro Vermelho and Madrepérola was similar to those of line VC-8 and of cultivar Majestoso (Figures $1 \mathrm{~b}$ and 2a). Majestoso accumulated more Mo per gram of seed tissue than VC-8 in three experiments (Figures 1a,b, and $2 \mathrm{a})$. However, because of the greater 100 -seed mass of VC-8 (31.4 g averaged across the four experiments) than that of Majestoso (28.2 g), these genotypes had similar SMoCt.

The black bean cultivars Ouro Negro and Valente were always in the group of genotypes with the lowest SMoCt (Figures 1 and 2). The Type II cultivars Pioneiro (Figure 2a,b) and Horizonte (Figures $1 \mathrm{~b}$ and $2 a)$, both of the carioca class, were in this group in two experiments. Cultivars Ouro Vermelho and Pérola were in the group with the lowest SMoCt in one experiment (Figure 1a).

On average, the SMoCt of Majestoso was $6.4 \mu \mathrm{g}$ and that of line $\mathrm{VC}-8,6.1 \mu \mathrm{g}$; in the other extreme, the SMoCt of Ouro Negro was $4.3 \mu \mathrm{g}$ and that of Valente, $3.4 \mu \mathrm{g}$. Therefore, the SMoCt of Majestoso was approximately $90 \%$ higher than that of Valente. These results indicate that the Mo rate required to enrich the seeds of Majestoso and VC- 8 by plant spraying may be lower than that required to enrich the seeds of Ouro Negro, and especially those of Valente. In common bean genotypes, the effect of the seed coat color on the Mo-accumulation capacity of the seed has yet to be studied in detail. Our results with foliar-applied Mo and the study of Franco \& Munns (1981) with Mo supplied via soil may indicate that black seed cultivars, such as, Ouro Negro and Valente, could accumulate less Mo in seeds than genotypes with other seed coat colors.

In Oratórios, all genotypes had SMoCt above $3.6 \mu \mathrm{g}$ (Figures 1a,b, and 2b). In Coimbra, five cultivars did not reach this seed content: Pérola, Ouro Negro, Pioneiro, Horizonte, and Valente (Figure 2a). Plants originated from seeds of these five genotypes grown in Mo-poor soil may respond favorably to Mo application (Vieira et al., 2011b).

Our results suggest that large-seeded cultivars can reach $3.6 \mu \mathrm{g}$ Mo per seed at Mo rates well below $600 \mathrm{~g} \mathrm{ha}^{-1}$. This Mo rate seems sufficient to increase Mo in seeds of Type III genotypes such as Majestoso, VC-8, Ouro Vermelho, and Madrepérola to $3.6 \mu \mathrm{g}$, even in soil with $\mathrm{pH} 4.7$ (as in Coimbra), where the Mo available in soil is 100 times lower than in soil with pH 5.7 (Lindsay, 1979). In a soil with $\mathrm{pH} 5.2$ in Coimbra, Vieira et al. (2010) sprayed plants of cultivar Pérola with $1000 \mathrm{~g} \mathrm{ha}^{-1}$ Mo to obtain $3.6 \mu \mathrm{g}$ Mo per seed. In the present study, Pérola was not among the genotypes with high capacity to accumulate Mo in seed, helping to explain the high Mo rate used by Vieira et al. (2010) to obtain 3.6 $\mu \mathrm{g}$ Mo per seed.

There were some indications that the lower SMoCc in Type I and Type II cultivars was due, at least in part, to the lower interception of the sprayed solution by the crop relative to that of Type III cultivars. However, since Type I cultivars generally have large seeds, they have higher SMoCt values than small seeds. Cultivars with Type II growth habit generally have small seeds. Therefore, our results suggest that, to raise SMoCt to $3.6 \mu \mathrm{g}$, Type II cultivars require a higher Mo fertilizer rate than both Type I cultivars and III cultivars that are good Mo accumulators in seed.

Canopy closure was only evaluated in Coimbra. In Oratórios, the differences in canopy closure among the cultivars with the three growth habits after Mo application were apparently similar to those in Coimbra. In 2008, plots consisted of one 2 -m row. This row was lined on either side by randomly 2 of the 11 other genotypes. Eight of the 12 genotypes were Type III. Plants of these genotypes are more competitive (have more intense growth) than Type I and type II plants. Thus, the probability of Type I and II plants to compete with Types III plants was higher, on either side of the row, than with Type I or Type II plants. Possibly, a bias was introduced by using borders of plants morphologically different from those in the plots. We believe, however, that this bias only had a minor influence on the results of SMoCc in 2008, because at the time Mo application, plants were either young (V4 stage, $50 \%$ of the Mo rate) or had not reached maximum growth (R6 stage). Moreover, the results of SMoCc of the genotypes in 2008 (bordered by other genotypes) were similar to those obtained in 2010 (bordered by the same genotype).

The common bean class carioca (beige with brown stripes) is the most commonly grown in Brazil, followed by the black class. Other relevant classes in certain regions are "manteigão" (all large-seeded genotypes), especially jalo (with beige seeds, e.g., Jalo MG-65), cranberry (e.g., Carnaval), and the red class (Paula Júnior et al., 2010). In Brazil, Type III cultivars are cultivated much more on common bean fields than Type II cultivars. In the case of Type I, few cultivars are available for growers (Vieira et al., 2006). In this study, we used genotypes from four research institutions to represent this variability of commercial classes and plant types.

\section{CONCLUSIONS}

1. Common bean genotypes vary in their capacity of accumulating foliar-applied molybdenum in the seeds.

2. Cultivar Majestoso has a high capacity of accumulating foliar-applied Mo in the seeds, unlike the cultivars Ouro Negro and Valente.

\section{ACKNOWLEDGEMENTS}

This research was funded by the Research Foundation of the State of Minas Gerais (Fapemig), 
Belo Horizonte, Brazil. The researchers R.F. Vieira, T.J. Paula Júnior, and J.E.S. Carneiro were supported by the National Council for Scientific and Technological Development (CNPq), Brasília, Brazil.

\section{LITERATURE CITED}

ABREU, C.A.; LOPES, A.S. \& SANTOS, G.C.G. Micronutrientes. In: NOVAIS, R.F.; ALVAREZ V., V.H.; BARROS, N.F.; FONTES, R.L.F.; CANTARUTTI, R.B. \& NEVES, J.C.L., eds. Fertilidade do solo. Viçosa, MG, Sociedade Brasileira de Ciência do Solo, 2007. p.645-736.

ALMEIDA, F.F.D.; ARAÚJO, A.P. \& ALVES, B.J.R. Seeds with high molybdenum concentration improved growth and nitrogen acquisition for rhizobium-inoculated and nitrogen-fertilized common bean plants. R. Bras. Ci. Solo, 37:367-378, 2013.

AMANE, M.I.V.; VIEIRA, C.; NOVAIS, R.F. \& ARAÚJO, G.A.A. Adubação nitrogenada e molíbdica da cultura do feijão na Zona da Mata de Minas Gerais. R. Bras. Ci. Solo, 23:643650, 1999.

BERGER, P.G.; VIEIRA, C. \& ARAÚJO, G.A.A. Efeitos de doses e épocas de aplicação de molibdênio sobre a cultura do feijão. Pesq. Agropec. Bras., 31:473-480, 1996.

BARBOSA, F.R. \& GONZAGA, A.C.O., eds. Informações técnicas para o cultivo do feijoeiro-comum na Região Central-Brasileira: 2012-2014. Santo Antônio de Goiás, Embrapa Arroz e Feijão, 2012. 247p. (Série Documentos, 272)

BRODRICK, S.J. \& GILLER, K.E. Root nodules of Phaseolus: Efficient scavengers of molybdenum for $\mathrm{N}_{2}$-fixation. J. Exp. Bot., 42:679-686, 1991a.

BRODRICK, S.J. \& GILLER, K.E. Genotypic difference in molybdenum accumulation affects $\mathrm{N}_{2}$-fixation in tropical Phaseolus vulgaris L. J. Exp. Bot., 42:1339-1343, 1991b.

BRODRICK, S.J.; AMIJEE, F.; KIPE-NOLT, J.A. \& GILLER, K.E. Seed analysis as a means of identifying micronutrient deficiencies of Phaseolus vulgaris L. in the tropics. Trop. Agric., 72:277-284, 1995.

CAMPO, R.J.; ARAUJO, R.S. \& HUNGRIA, M. Molybdenumenriched soybean seeds enhance $\mathrm{N}$ accumulation, seed yield, and seed protein content in Brazil. Field Crops Res., 110:219-224, 2009.

EMPRESA BRASILEIRA DE PESQUISA AGROPECUÁRIA EMBRAPA. Centro Nacional de Pesquisa de Solos. Sistema brasileiro de classificação de solos. Rio de Janeiro, 2006. 306p.

FRANCO, A.A. \& MUNNS, D.N. Response of Phaseolus vulgaris $\mathrm{L}$. to molybdenum under acid conditions. Soil Sci. Soc. Am. J., 45:1144-1148, 1981.

GUANG-YI, L.; YI-PING, L.; HONG, Z.; ZHAN-FANG, C. \& ZHENG-HE, X. A novel approach for the preferential flotation recovery of molybdenite from a porphyry coppermolybdenum ore. Miner. Eng., 36-38:37-44, 2012.
JACOB-NETO, J.; THOMAS, R.J. \& FRANCO, A.A. Variação estacional da concentração do molibdênio nos nódulos e demais partes da planta de feijoeiro (Phaseolus vulgaris L.). Turrialba, 38:51-58, 1988.

KANE, M.V. \& GRABAU, L.J. Early planted, early maturing soybean cropping system: Growth, development and yield. Agron. J., 84:769-773, 1992

KAISER, B.N.; GRIDLEY, K.L.; BRADY, J.N.; PHILLIPS, T. \& TYERMAN, S.D. The role of molybdenum in agricultural plant production. Ann. Bot., 96:745-754, 2005.

KUBOTA, F.Y.; ANDRADE NETO, A.C.; ARAÚJO, A.P. \& TEIXEIRA, M.G. Crescimento e acumulação de nitrogênio de plantas de feijoeiro originadas de sementes com alto teor de molibdênio. R. Bras. Ci. Solo, 32:16351641, 2008.

LINDSAY, W.L. Chemical equilibria in soils. New York, John Wiley \& Sons, 1979. 499p.

MENDEL, R.R. Cell biology of molybdenum in plants. Plant Cell Rep., 30:1787-1797, 2011.

PACHECO, R.S.; BRITO, L.F.; STALIOTTO, R.; PÉREZ, D.V. \& ARAÚJO, A.P. Seeds enriched with phosphorus and molybdenum as a strategy for improving grain yield of common bean crop. Field Crops Res., 136:97-106, 2012.

PAULA JÚNIOR, T.J.; CARNEIRO, J.E.S.; VIEIRA, R.F.; ABREU, A.F.B.; RAMALHO, M.A.P.; del PELOSO, M.J. \& TEIXEIRA, H. Cultivares de feijão-comum para Minas Gerais. Belo Horizonte, 2010. 40p.

PESSOA, A.C.S.; RIBEIRO, A.C.; CHAGAS, J.M. \& CASSINI, S.T.A. Atividades de nitrogenase e redutase de nitrato e produtividade do feijoeiro "Ouro Negro" em resposta à adubação foliar com molibdênio. R. Bras. Ci. Solo, 25:217$224,2001$.

SILVA, M.V.; ANDRADE, M.J.B.; RAMALHO, M.A.P. \& ALVES, V.G. Aplicação foliar simultânea de molibdênio e alguns defensivos agrícolas na cultura do feijoeiro. Ci. Agrotec., 27:1160-1164, 2003.

VIEIRA, C.; NOQUEIRA, A.O. \& ARAUJO, G.A.A. Adubação nitrogenada e molíbdica na cultura do feijão. R. Agric., 67:117-124, 1992.

VIEIRA, C.; PAULA JÚNIOR, T.J. \& BORÉM, A. Feijão. 2 .ed. Viçosa, MG, Universidade Federal de Viçosa, 2006. $600 \mathrm{p}$.

VIEIRA, R.F.; SALGADO, L.T. \& FERREIRA, A.C.B. Performance of common bean using seeds harvested from plants fertilized with high rates of molybdenum. J. Plant Nutr., 28:363-377, 2005.

VIEIRA, R.F.; SALGADO, L.T.; PIRES, A.A. \& ROCHA, G.S. Conteúdo de molibdênio das sementes de feijoeiro em resposta a doses do micronutriente pulverizado sobre as plantas. Ci. Rural, 40:666-669, 2010.

VIEIRA, R.F.; FERREIRA, A.C. \& PRADO, A.L. Aplicação foliar de molibdênio em feijoeiro: conteúdo do nutriente na semente e desempenho das plantas originadas. Pesq. Agropec. Trop., 41:163-169, $2011 \mathrm{a}$. 
VIEIRA, R.F.; PAULA JÚNIOR, T.J.; PIRES, A.A.; CARNEIRO, J.E.S. \& ROCHA, G.S. Common bean seed complements molybdenum uptake by plants from soil. Agron. J., 103:1843-1848, 2011b.
WILLIAMS, C.M.J.; MAIER, N.A. \& BARTLETT, L. Effect of molybdenum foliar sprays on yield, berry size, seed formation, and petiolar nutrient composition of 'Merlot' grapevines. J. Plant Nutr., 27:1891-1916, 2004. 